Alicante Journal of English Studies / Revista Alicantina de Estudios Ingleses

ISSN: 0214-4808 | e-ISSN: 2171-861X

Issue No. 36, 2022, pages 29-53

https://doi.org/10.14198/raei.2022.36.02

\title{
Critical Literacy in ELT Classroom Testing
}

\section{A. Vimieiro Pascoal \& A. Machado de Almeida Mattos}

\begin{abstract}
Author:
Lílian Aparecida Vimieiro Pascoal

Federal University of Minas Gerais, Brazil

lilianapvimieiro@gmail.com

http://orcid.org/0000-0003-3706-4860

Andrea Machado de Almeida Mattos

Federal University of Minas Gerais, Brazil andreamattosufmg@gmail.com

https://orcid.org/0000-0003-3190-7329

Date of reception: 13/02/2021

Date of acceptance: $27 / 04 / 2021$

Citation:

Pascoal, Lílian Aparecida Vimieiro and Andréa Machado de Almeida Mattos. 2022. "Critical Literacy in ELT Classroom Testing." Alicante Journal of English Studies 36: 29-53.

https://doi.org/10.14198/raei.2022.36.02

(C) 2022 Lílian Aparecida Vimieiro Pascoal \& Andrea Machado de Almeida Mattos

Licence: This work is licensed under a Creative Commons Attribution 4.0 International License (CC BY 4.0)

(c) (i)
\end{abstract}

\begin{abstract}
:
Critical Literacy (CL) has lately influenced English Language Teaching (ELT) in Brazil, mainly after the publication of the National Guidelines for High School Teaching, and several practitioners have started to use CL perspectives in their ELT contexts. Besides, CL and Critical Language Education have been the focus of much research in Brazil. Nonetheless, these alternative approaches have not yet made their way into testing and assessment. This paper focuses on the relationship of $\mathrm{CL}$ and English Language testing. First, we present an overview of important concepts in the area of testing and assessment in ELT. We also discuss important concepts of CL and other critical approaches to ELT. Then, we briefly discuss the possibility of using CL together with CA in English teaching. To illustrate, we summarize a course in ELT, which has used CL and CA at university level. Finally, considering tests as part of the social practices in educational contexts, we demonstrate that, just as CL may be used for Citizenship Education and Social Justice in English classes, the same approach should be used when testing, particularly due to the use of language as a tool for social reconstruction and critique for the exposure of inequalities. Principles for developing critical practices in testing and assessment are discussed along the paper.
\end{abstract}

Keywords: Language Teaching, Evaluation, Critical Literacy, Teacher Education 


\section{Introduction}

Critical Applied Linguistics, as proposed by Pennycook (2001) and others, has now influenced many areas of professional practice and scientific research in the field of English Language Teaching (ELT) and Language Teacher Education (LTE). However, in our view, testing - especially classroom language testing - is still an area where more critical perspectives have not yet made an impact on either research or practice. Critical Literacy (Cervetti, Pardales \& Damico 2001; McLaughlin \& DeVoogd 2004) has lately influenced ELT in Brazil, mainly after the publication of the National Guidelines for High School Teaching, in 2006, and several classroom practitioners have started to use Critical Literacy (CL) perspectives together with the Communicative Approach (CA) (Mattos \& Valério 2010; Valério \& Mattos 2018) in their ELT contexts. In the same vein, CL and Critical Language Education (Ferraz 2010, 2015; Mattos, Ferraz \& Monte Mór 2015; Monte Mór 2009) have been the focus of much research in Brazil. Nonetheless, these alternative approaches have not yet made their way into testing and assessment, despite the evidence of the roles played by language testing on social and political levels (Shohamy 2004).

This paper ${ }^{1}$ focuses on the possible relationship of Critical Literacy and English Language testing in critical teaching contexts, since it is a meaningful effort in order to understand classroom practices, and further actions towards a more consistent use of tests in regards to teaching perspectives, methods, philosophies, and approaches.

First, we present an overview of important concepts in the area of classroom testing and assessment, especially in ELT. We also describe and discuss important concepts of Critical Literacy and other critical approaches to ELT. Then, we briefly discuss the possibility of using CL together with CA in teaching English as an additional language. To illustrate, we will summarize a course in ELT, which has used CL and CA at university level (Mattos 2014, 2018a). Finally, considering tests as part of the social practices in educational contexts, the main objective is to demonstrate the association to the fact that, just as CL may be used for Citizenship Education (Vetter 2008) and Social Justice (Hawkins 2011; Mattos 2014) in English classes, the same approach should be used when testing (Pascoal

1 This paper was partially funded by a grant to the first author during her M.A., by CAPESCoordenação de Aperfeiçoamento de Pessoal do Ensino Superior, and to the second author, Researcher Level Pq2 at CNPq-National Council for Scientific and Technological Development (Process n. 308243/2020-0); The two authors of this paper are researchers at NECLLE-Núcleo de Estudos Críticos sobre Linguagens, Letramentos e Educação (Centre for Critical Studies on Languages, Literacies and Education), at the Federal University of Minas Gerais, a registered group at the (CNPq). 
2018), particularly due to the use of language as a tool for social reconstruction and critique for the exposure of inequalities. In doing so, we also try to elaborate on possible principles for developing critical practices in testing and assessment in the language classroom.

\section{Important concepts in classroom testing and assessment}

As a research subject in Applied Linguistics, assessment has been constantly revisited (Alderson $\&$ Banerjee 2002), which signals an important movement. Grillo and Lima (2010) indicate that this allows the integration of new contexts, new information, and a dynamic expansion of the term.

As a practice, assessment may be used in distinct circumstances, incidentally or intentionally (Brown 2004). Assessments have, as most practices, intentional and unintentional consequences, and can affect teaching, learning and general social life contexts (Scaramucci 2011).

According to Davis, in language teaching, "evaluation, assessment, and testing are used for achieving a common aim: enabling individuals to better understand and change any of the elements that constitute language programs" (2018, 5255). The author says evaluation, assessment and testing may be taken as points on a continuum, in which evaluation takes the broadest possible perspective on a wide range of programmatic functions and processes, and assessment is a more narrowly focused term directed toward student learning. The author also states that, although testing may present definitions and practices that overlap with those referring to assessment, "certain widely held connotations suggest that testing is more narrowly focused than assessment" $(2018,5256)$. Others that, in the past, have argued in the same vein are Ur (1996) and Genesee and Upshur (1996). In this sense, evaluation may be considered an umbrella term encompassing both assessment and testing.

Brown defines assessment as the ongoing process that is intrinsically connected to teaching. Thus, for the author, "a good teacher never ceases to assess students" $(2004,4)$. In such process, teachers can use different tools to observe and assess, including tools that admit self or peer assessment. Fulcher and Davidson (2007) assert that assessing is a meaningful action and, ideally, presents the purpose of enlightening teaching and learning, stimulating the reflexive action upon improving teaching and enhancing learning efficiency.

Therefore, in ELT classroom assessment contexts, a great variety of procedures and tasks may be employed according to perceived needs and purposes. They are in the generalized spectrum of summative, formative or diagnostic assessment. 
One of the long-lasting debates in teaching — and testing — any subject is the debate over summative and formative assessment. In ELT it is just the same. Summative assessment refers to the action of testing students after a certain point in the curriculum, for instance, the end or the middle of a course or unit, to check their understanding and their development (Brown 2004). According to Brown (2004), the teacher has a choice to change summative test, a test that is used to translate what students have learnt into quantitative information, into a more formative test, turning it into an opportunity to learn, not only an opportunity to generate data, namely numbers as grades and scores. Goertel more recently defines summative assessments as types of evaluation that are "used to determine if students have mastered specific competencies and to identify instructional areas that need additional attention" and formative assessment as types of evaluation "used to provide ongoing direction for improvement and/or adjustment in learning and instruction" $(2018,2053)$.

Formative assessment encompasses a wider variety of assessment practices, not only testing. The assessment aims to inform the teacher about the learning process but in a way that helps the parties to focus on the students' growth, the development of skills and an array of competences. Formative assessment may be done as informal assessment and, in this case, one example that is given by Brown (2004) is comments and informal feedback from the teacher. There must be a means of delivering this feedback that is understood by teachers and students, and an internalization on the students' end. Both actions allow the continuation of the process and, therefore, the students' growth.

Considering classroom environments, diagnostic assessment is reported by Brown (2004) as tests done in the beginning of a course or before specific topics or skills have been taught or developed in a given class. This type of assessment may also be considered a sub-type of formative assessment (Boraie 2018). Luckesi (2008) analyzes the distinction made firstly by Freire (1975) who explores the students' domestication and humanization as two opposite pedagogical directions. Luckesi (2008) couples these thoughts to the contemporary assessment practices. According to the author, the domestication pedagogy uses assessment as a controlling and disciplinary tool "not only regarding cognitive behaviors, but also social ones" (2008, 32). As for the humanization pedagogy, in this case assessment is used as a means for diagnostic, not as a controlling mechanism, but as a democratic tool that allows for students' autonomy and that aims at improvement and growth.

In any test, whether it is diagnostic, summative, or formative with a summative tendency, the test maker must make decisions beforehand. This is because, in order to have good information about what is sought, the test needs to be a well-informed test, in terms of how to collect and why to collect the 
information (Hughes 1989). Aspects such as the types of items created, language used in stimuli and in instructions, and the response expected from the test takers are some of the decisions to be made.

In addition, some other aspects need to be taken into account, for example, the practicality, validity, and reliability of a test. Practicality refers to the aspects that make a test practical, and, as Brown (2004) asserts, these can be aspects such as the amount of money, time, and personnel involved in the process as a whole, from the preparation of the test to the scoring. Such an aspect has to do with costs. Hughes argues that, besides reflection upon the test characteristics regarding being "easy and cheap to construct, administer, score and interpret", it is also important to ask questions that focus on the costs "of not achieving beneficial backwash" $(1989,47)$.

Washback effect, also named backwash effect, refers to the impact, influence or consequence of a test (Quevedo-Camargo 2014). Alderson and Banerjee (2001) describe test washback as a complex aspect, given the fact that there are many factors influencing its nature. Washback, as the authors point out, is the impact tests may have on teaching and learning, which can be either negative, in the case of a bad test, or positive, in the case of a good one (Alderson $\&$ Banerjee 2002). Richards and Schmidt define the term on an even broader manner, considering washback effect as the impact of a test on "individual test takers, other stakeholders (e.g. teachers, parents, school administrators, or test developers), educational systems, or society" $(2010,272)$. As the authors construe such an effect, they rephrase that the impact of a test can cause the teachers to teach to the test, that is to say that the teachers would focus on teaching the tests' abilities or skills:

For example, if the education department in a country wanted schools to spend more time teaching listening skills, one way to bring this about would be to introduce a listening comprehension test component into state examinations. The washback would be that more class time would then be spent on teaching listening skills. When teaching is found to exert an important effect on testing, this impact is called a reverse washback (Richards \& Schmidt 2010, 634).

What the authors mention is one of the possible scenarios of washback effect on teaching environment, through the perspective of large-scale tests, in which the decisions fall on the education department hands. Other circumstances in which tests change teaching and/or learning practices may also be found. However, these will not be discussed here as this is not the focus of this paper.

Other important aspects of tests are validity and reliability. According to Hughes, "a test is said to be valid if it measures accurately what it is intended to 
measure" $(1989,22)$. There are four types of validity: content validity, criterionreferenced validity, construct validity, and face validity. According to Palmer and Bachman (1981), content validity considers that the tasks proposed on a test are coherent to the content it intends to assess. To investigate the content validity of a test, one needs to sample and describe the competences being tested. Criterion-referenced validity is seen by the authors as controversial, due to the nature of this type of validity. It refers to "the extent to which a test predicts something that is considered important" (Palmer \& Bachman 1981, 136), but when a test shows this validity, it may not mean that what the test measures is known, in other words, it may not be clear enough. Construct validity is used to support positions through hypothesis formation and testing, and it allows one to understand the competence of test takers, according to the "relationship between a test and the psychological abilities it measures" (Palmer \& Bachman 1981, 136). Finally, the authors also discuss face validity, which is considered the least important of the four types, due to the lack of statistics or procedures involved in the process of measuring it. Palmer and Bachman state that a test exhibits face validity when it seems like it measures what it is supposed to measure $(1981,135)$.

A more recent approach to validity in assessment research considers it as an argument used, by any stakeholder, to understand and use a test, and the reliability as the evidence of validity (Scaramucci 2011). Reliability has been termed as the consistency of a test that measures what the test assesses. Fulcher and Davidson (2007) consider the consistency of a test, which entails that, if replicated, it should have an interpretable and meaningful score, and should also be reproducible. A reliable test is built considering that the answers given by students are the only factor that would change the scores, for instance, ensuring that the response to a test item relies only on this item, and does not depend on another, or that enough items were included to have a meaningful score (Fulcher \& Davidson 2007).

Language assessment and language pedagogy are intertwined areas. Hancock (2006) defends that the validity and the reliability of a test depend on the alignment between teaching and testing. For instance, the methodology, tools, activities, philosophical position, and theoretical foundation or practical experiences in which teachers might base their choices and decisions must find their way in the tests. If this is so, critical approaches to English language teaching (ELT) must be considered when designing a test in a course based on such approaches. For this reason, in the next section, we discuss recent developments in the area of critical approaches to ELT, more specifically, Critical Literacy, which will help us support our arguments for using this same approach in testing. 


\section{Critical literacy in English language teaching and testing}

Lately, researchers and practitioners in the area of language teaching have been prioritizing more critical perspectives, drawing on the work of Pennycook (2001), who makes a case for Critical Applied Linguistics (for a quick review, see for example Mattos, 2018b). In Brazil, these more critical perspectives in language teaching have recently experienced a boom, especially after the publication of the National Guidelines for High School Teaching (Brazil 2006), when Critical Literacy (CL) was officially presented as a suggestion for teaching English at High School level, with the objective of teaching language for citizenship education and social transformation. The document advances pedagogical suggestions that emphasize the representations and analysis of differences, such as background, race, sexuality, gender, class, and discussions about who wins or loses in certain social relationships. The document also proposes a view of language as sociocultural practice as well as a view of learning as meaning-making. Based on critical literacy perspectives, the suggestions seek to develop students' critical conscience on various social practices and on the possibility of feelings of oppression or exclusion that may be generated in those who are not allowed/don't want to participate.

Crookes understands $C L$ as an overarching term for several critical pedagogical proposals for language teaching that "invite the language user and learner to develop tools for seeing the ways in which language has position, interests, power, and can act to disadvantage those on the lower rungs of a hierarchical society" $(2013,28)$. According to Janks, critical literacy is not a teaching methodology per $s e$, but a perspective or a point of view, a way to look at the world and to interpret it through diverse lenses. Janks states that "essentially, Critical Literacy is about enabling young people to read both the word and the world in relation to power, identity, difference and access to knowledge, skills, tools and resources. It is also about writing and rewriting the world" $(2013,227)$.

Cervetti, Pardales and Damico (2001), in a groundbreaking article, compare and contrast the origins, perspectives and objectives of two educational possibilities: critical literacy and critical reading. The authors say that, although the two perspectives have a few points in common, since both are approaches to literacy, they also differ in many ways. Besides having different theoretical origins, as the authors discuss, the two perspectives also present different visions of how knowledge, reality, authorship and discourse should be understood. Moreover, critical reading and critical literacy also present different perspectives on the objectives of education. Cervetti, Pardales and Damico (2001) define critical reading as a set of skills that allow the reader to "investigate sources, recognize the purpose of an author, distinguish fact and opinion, make inferences, form judgments, and detect propaganda strategies" $(2001,42)$. These skills, which 
extend the capacities of the individual beyond what has been called functional literacy (Castell, Luke \& MacLennan 1986; Soares 1998), allow for "higher levels of analysis and understanding," as asserted by Cervetti, Pardales and Damico (2001, 42), but need to be taught explicitly, since they do not develop naturally in readers. Critical literacy, however, has even more ambitious goals.

Bond and Wagner clarify that "critical reading is the process of assessing the authenticity and validity of material and formulating opinions about it" (1966, 283). Contrary to critical reading, in critical literacy the aim of readers is not to evaluate or to formulate opinion, but to construct meanings from the text. Moreover, according to Cervetti, Pardales and Damico, in the perspective of critical literacy, "textual meaning is understood in the context of social, historical and power relations, not just as the product or intention of an author" (2001, 46). Therefore, the process of reading, as Freire and Macedo (1987) have posed, come to be seen as a process of knowledge of the world, and not only of the word (or written text), and is aimed at social transformation.

McLaughlin and DeVoogd argue that critical literacy considers "readers as active participants in the reading process and invites them to move beyond passively accepting the text's message to question, examine, or dispute the power relations that exist between readers and authors" $(2004,14)$. These authors agree with Cervetti, Pardales and Damico (2001), when they say that critical literacy "promotes reflection, transformation, and action" (McLaughlin \& DeVoogd 2004, 14), according to the Freirian view of social transformation. Morgan asserts that the practice of critical literacy leads readers to question "who constructs the texts [or perspectives / discourses / ideologies] whose representations are dominant in a particular culture at a particular time; how readers come to be complicit with the persuasive ideologies of texts; whose interests are served by such representations and such readings; and when such texts and readings are inequitable in their effects, how these could be constructed otherwise" (1997, 2).

Thus, critical literacy highlights the power relations that prevail in our society and is especially concerned with the differences between race, social class, gender, sexual orientation, etc., examining them "not as isolated occurrences but rather as part of systemic inequities and injustices", as Cervetti, Pardales and Damico $(2001,46)$ point out. Some of the major concerns of critical literacy are summarized in Table 1 below. 
TABLE 1. Main concepts of Critical Literacy

(adapted from Cervetti, Pardales \& Damico 2001, 50)

\begin{tabular}{ll}
\hline \multicolumn{1}{c}{ Area } & \multicolumn{1}{c}{ Critical Literacy } \\
\hline $\begin{array}{l}\text { Knowledge } \\
\text { (epistemology) }\end{array}$ & $\begin{array}{l}\text { What counts as knowledge is not natural or neutral; knowledge is } \\
\text { always based on the discursive rules of a particular community, and is } \\
\text { thus ideological. }\end{array}$ \\
\hline $\begin{array}{l}\text { Reality } \\
\text { (ontology) }\end{array}$ & $\begin{array}{l}\text { Reality cannot be known definitively, and cannot be captured by } \\
\text { language; decisions about truth, therefore, cannot be based on a theory } \\
\text { of correspondence with reality, but must instead be made locally. }\end{array}$ \\
\hline Authorship & $\begin{array}{l}\text { Textual meaning is always multiple, contested, culturally and historically } \\
\text { situated, and constructed within differential relations of power. }\end{array}$ \\
\hline $\begin{array}{l}\text { Instructional } \\
\text { goals }\end{array}$ & Development of critical consciousness \\
\hline
\end{tabular}

Cervetti, Pardales and Damico (2001) argue that the foundations of critical literacy are based on revolutionary values, stemming from the assumptions of critical social theory, but also based on Paulo Freire's Critical Pedagogy (Freire 1982; 1984) and his view of language as an empowering element. According to Mattos, critical literacy is "committed to values such as justice and equality, [and] aims at promoting social change, inclusion of marginalized groups and citizenship education" $(2014,129)$.

More recent research on Critical Literacy in language classrooms, and especially in ELT contexts, have also tried to make the case for critical language teaching. According to Dooley, Exley and Poulus, research on introducing Critical Literacy in English teaching has lately flourished and a "key finding [...] is that English can indeed be taught critically to second language learners-in EFL settings such as Taiwan [and Brazil], as well as in English-dominant settings such as Australia, the UK or the US" $(2016,39)$. The authors state that critical literacy is an instrument of justice and define it as "an act of cultural and political power dedicated to the pursuit of human freedom, equality and emancipation" (2016, 39). Based on the political philosophy of Nancy Fraser and her multidimensional model for conceptualizing (in)justice, the authors explain that "Critical literacy is often concerned with the ways that differences of culture, race, gender and so forth are construed" $(2016,41)$. Their effort in the article is focused on reviewing some Critical Literacy in EFL setting programs in order to try to answer the question of "whether and how critical literacy programs achieve their emancipatory promise" $(2016,61)$. The programs these authors have reviewed seem to provide instruction on critical thinking and tried to juxtapose critical teaching with more conventional pedagogy, as well as ensuring textbook critique. 
One of the main concerns mentioned by the authors "are the constraining effects of one or another examination or testing regimen" $(2016,61)$, a topic we also address here. Huh (2016) revises several instructional models of critical literacy and also discusses the possibility of balancing more conventional pedagogy and critical literacy perspectives in EFL contexts.

Bobkina and Stefanova also argue in favor of introducing Critical Literacy into the language classroom, this time through the use of literature. They contend that critical language teaching "has recently been enhanced by scholars who argue for the need of introducing critical literacy pedagogy into the language teaching curriculum as a means of promoting social justice" (2016, 679; italics in the original). The authors present a model for teaching critical thinking skills, which involves "interpretation of the world; self-reflection; critical awareness; intercultural awareness; reasoning and problem-solving and language use" (p. 684) and they offer a detailed example of how to apply the model. In Brazil, some researchers have also developed possible models and principles for using critical literacy in the EFL classroom with detailed practices and examples of activities. For example, Valério and Mattos (2018) have used film as input text for critical practices in the EFL classroom, and Duboc (2013) has proposed a similar model as the one developed by Bobkina and Stefanova (2016).

In another paper on the inclusion of Critical Literacy practices in an EnglishSpanish bilingual dual language classroom, Esquivel discusses a case study which "examined the power discourses and the critical literacy practices that help Latinx bilingual students become critical readers, negotiate meaning, and enhance their literacy skills in English and Spanish" $(2019,207)$ by incorporating several types of activities with the aim of enhancing students' critical skills and disrupting power discourses present in texts and images. Using Critical Discourse Analysis (CDA) as the theoretical framework, the author analyses discussions and writings produced by the students, as well as their drawings, from a CDA and social semiotics perspective. Results show that "the participants' experiences, funds of knowledge, and power discourses were essential components for completing the activities" and in the dual language classroom, "issues of power, discrimination, and injustices were addressed bilingually" (Esquivel 2019, 224). According to the author, "The participants used critical literacy practices to reaffirm and become conscious of the systems and institutions that subjugate people to advantaged and disadvantaged social functions" (2019, 224).

Although critical literacy is not a methodology in itself, but a perspective or attitude as we have seen, it may be coupled with language teaching methods, such as the Communicative Approach (Mattos \& Valério 2010; Valério \& Mattos 2018), and used as an approach to classroom teaching. However, in doing so, evaluation also has to follow critical perspectives, as highlighted in Pascoal (2018). 
Grillo and Lima (2010) explain the pedagogical activity as having three processes at play: teaching, learning and assessment. These processes affect each other and exist in one another. Moreover, the authors consider that assessments translate the teachers' theoretical and methodological beliefs. Therefore, as discussed in Pascoal (2018), a course based on critical perspectives and citizenship promotion must follow the same direction when it comes to assessments, either formal or informal. Otherwise, at least two issues soon come to mind: The first is the lack of actual evidence on the development of learners' competencies and skills, especially those worked with during or after lessons; The second refers to the course validity and reliability in itself. Such a rupture of rationale, curriculum coherence and consistency, may create confusion and mistrust among stakeholders, along with the possibility of lowering student's levels of motivation. These issues are related to, respectively, learning and teaching processes in the pedagogical activity when assessment processes do not follow the same directions.

\section{Becoming critical in testing}

In keeping with the principles of critical literacy in teaching and testing, which will be discussed ahead, in this section we will describe and discuss two of the evaluation procedures used in an introductory undergraduate course for firstyear English Majors preparing to become English teachers, at a big university in Brazil, namely the Final Written Test and the Oral Test.

The course in which these evaluation procedures were used was designed based on the principles of Critical Literacy, using the Communicative Approach as the main teaching methodology (Mattos \& Valério 2010; Valério \& Mattos 2018). Although this is an introductory course, the students enrolled usually present an intermediate level of proficiency in English. This course has been taught with this content since 2011 during a whole semester (60 hours). The course is fully taught in English and both authors of this paper have taught it several times.

In general terms, the course involves integrated practice of the four language skills, such as oral and written production and oral and written comprehension, grammar and vocabulary micro-skills, as well as an initial focus on pronunciation and introductory notions of phonology ${ }^{2}$. The themes and activities included in the course seek to provide students with opportunities for critical reflection on questions of social inequality and spaces to dispute some of the established truths in our society and, at the same time, their own introjected truths and

2 For more details on the course itself and its proposal, see Mattos (2014). 
beliefs. The main objective of these activities is to promote reflection on some critical issues that contribute to social injustices and unequal power relations in our society. The course is organized around four different projects, each focusing on a specific critical issue that is the focus of the reflection carried out in classroom. The projects are developed over 4 to 5 weeks with class meetings twice a week. The themes covered during the course include critical issues such as stereotypes, gender roles, and various types of physical, mental and virtual violence that may be common nowadays. Each project also includes a linguistic focus, which is selected from among the several possibilities offered by the texts chosen for the discussion of each theme. Table 2 below summarizes the themes and the linguistic content included in the course.

TABLE 2. Course summary (adapted from Mattos 2014)

\begin{tabular}{|c|c|c|c|c|}
\hline & Project I & Project II & Project III & Project IV \\
\hline Themes & Stereotypes & $\begin{array}{c}\text { Gender } \\
\text { differences }\end{array}$ & The cyber world & Bullying/violence \\
\hline $\begin{array}{l}\text { Linguistic } \\
\text { Focus }\end{array}$ & $\begin{array}{l}\text { The English verb } \\
\text { system (time, } \\
\text { tense and aspect) }\end{array}$ & If-clauses & Modals & Modals (cont.) \\
\hline
\end{tabular}

The assessment of student learning in the course uses summative and formative formats, as required by the university, seeking to evaluate students both throughout the learning process and at the end of the course. The types of assessment used have always sought to follow the precepts of the communicative approach in relation to evaluation, aiming also to test the four language skills and the micro-skills in a balanced way and with a focus on the communicability of the proposed tasks. To name a few, there are writing tasks that focus on academic writing, paragraph writing more specifically, in which the assessment is done by the comments and conversations between teacher and students, in a formative manner; another example is the production of vlogs, as a way of furthering the speaking practice of students and of creating opportunities for them to express themselves in ways that they couldn't have done in the classroom in front of more than forty other students, either due to time constraints or their own choice. Both examples of tasks are connected to the themes and integrate more than one skill.

During the course, two written tests are used, one in the middle of the semester (Mid-Term Test) and one at the end of the semester (Final Test), in addition to an oral test, also applied at the end of the semester. These three types of assessment are considered summative, as they test the students' knowledge at the end of the learning process in an objective way, assigning them a formal grade. However, both 
the written and oral tests have been designed to mirror the types of critical activities developed in classes. Thus, the texts used to test written and oral comprehension skills also address the same critical issues already discussed during the semester, such as gender differences and violence against women. Due to reasons of space and focus, in this paper we will only discuss the Final Written Test and the Oral Test.

The Final Written Test is composed of four integrated sections: listening, reading, language in use, and writing. As the last critical theme discussed in the course relates to several types of violence, we have chosen to use this theme also in the test throughout the several activities. We intend to go through the principles of Critical Literacy and the Communicative Approach perspectives as we discuss each section of the test. We believe that tests should also be used as a further chance to teach issues that are relevant for students' growth and improvement of critical thinking. Since teaching, learning and assessing are processes that affect each other greatly, in assessing, teachers should include teachable experiences for the students as well (Grillo \& Lima 2010). They may rely on expanding a theme through reading, adding vocabulary, exploring critical thinking and making students rethink their own opinions and those of others', or on analyzing their assessment results and learning from them.

\subsection{The Listening Section}

Stemming from what we have discussed previously, for the listening section of the test, we chose an authentic text for the listening input. According to the principles of the Communicative Approach, which in this case correspond to the perspectives of Critical Literacy teaching (Mattos \& Valério 2010; Valério $\&$ Mattos 2018), authentic texts are those developed to circulate in society as social literacy practices and not texts which are designed and/or adapted with the only purpose of teaching English. The purpose of the listening section is to check students' comprehension of aural stimuli. However, this text also allows for critical thinking and connecting students' previous knowledge and social experiences to the content of the test and their language learning practices. In choosing this text for the listening section, we had in mind its potential to explore social issues and to foster a sense of responsible citizenship.

The listening section of the test used a commercial ${ }^{3}$ by Budweiser on the responsibility of not driving after drinking, an issue intended to raise critical awareness of students and aiding in their education as critical citizens. Besides, this topic is related to the topic of violence as discussed during classes. The

3 Available at https://www.youtube.com/watch?v=56b09ZyLaWk (Last accessed on December 5th, 2015). 
commercial is only about a minute long and brings a song that talks about making a plan to always come home to those you love. The short film portrays a young man and his dog, from the moment he brings the puppy home and all the moments they share together, such as playing, sleeping on the couch and going out with friends. One night the dog is left alone at home while his owner goes out to drink with friends. The dog waits the whole night for his owner who is taking too long to get back home. During the commercial, a song is played, which talks about coming home for those who are waiting for you, while on the screen we see sentences saying "for some, the waiting never ended". The end of the commercial is surprisingly happy, which gives students a sense of hope in humankind. We used the lyrics of the song and the sentences used by the young man to test students' listening skills (task 1) and the sentences written on the screen to test their critical thinking (task 2), as shown in Figure 1 below.

FIGURE 1. Final Written Test, Listening Part

\begin{tabular}{|c|c|}
\hline \multicolumn{2}{|c|}{$\begin{array}{l}\text { Part I- Listening } \\
1 \text { - You are going to watch a short promotional video by Budweiser. After watching it } \\
\text { for the first time, read the texts below and fill in the blanks provided with one word only } \\
\text { or a contraction. The video will be played twice for you to check your answers. The first } \\
\text { letter of each word has been provided to help you. }\end{array}$} \\
\hline Boy & Song \\
\hline \multicolumn{2}{|l|}{ Welcome h__ buddy! } \\
\hline & 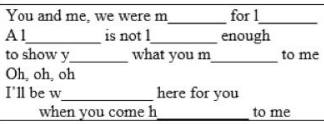 \\
\hline \multicolumn{2}{|l|}{ I'll s___you $1 \ldots$ buddy. } \\
\hline & 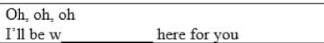 \\
\hline \multirow{4}{*}{\multicolumn{2}{|c|}{ 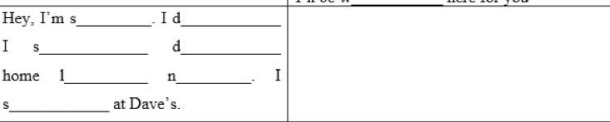 }} \\
\hline & \\
\hline & \\
\hline & \\
\hline & $\begin{array}{l}\text { Oh, oh, oh } \\
\text { when you come h }\end{array}$ \\
\hline I'm back. I'm back. Yeah, I'm back. & \\
\hline \multicolumn{2}{|c|}{2 - Now answer these two questions about the video: } \\
\hline \multicolumn{2}{|c|}{ a) What is the message Budweiser is trying to convey? } \\
\hline b) How do the lyrics of the song reflec & the message Budweiser is trying to send? \\
\hline
\end{tabular}

As we can see, the first task assesses students' listening skills through a listening cloze (Brown 2004). The blanked words were carefully chosen to explore listening and not to allow students to use only their reading skills to respond, which shows that it is a valid listening task. However, in order to make things a little easier to students with lower proficiency skills, the first letter of each missing word was provided. The second task explores the students' critical thinking through two open-ended questions. Both questions ask for students' interpretation of either 
the situation presented or the song. As it would seem, scoring the task may not show much practicality and may affect levels of reliability, due to the nature of a critical thinking practice and a short answer production. A short response of a communicative interpretation procedure, which involves authentic text comprehension and production, may generate different answers from students, and the teacher may take a significant amount of time scoring and considering them. However, for the purposes of the course in hand, these open-ended questions do not present themselves as bad options, since the course design has at its core the empowerment of the learner's critical stands, experiences that may foster the expression of learner's voice, and the encouragement of different length productions, which are all principles in Critical Literacy perspectives. The purpose of such questions, then, is not simply to identify the message underlying the stimuli, but to identify and interpret it with the learner's own voice on a theme that contributes to citizenship education, which had already been covered in previous class experiences. Therefore, the main purpose is achieved by providing students with opportunities to reflect critically on the topic and to further develop critical awareness on the issue. A critical teachable moment is, thus, provided by the test.

\subsection{The Reading Section}

As mentioned in Table 2, there is a range of social issues that were approached during the course. For the reading section, we chose a text that explores issues previously discussed in class, so students could activate their background knowledge on the subject. Besides the theme, once again we also observed and attended to the authenticity of the text. Having such a meaningful experience in tests allows students to notice language in use beyond the classroom context.

When it came to attending to language structure and covered vocabulary during the course, we considered ${ }^{4}$ which experiences students had in class during the course, and used this section as a chance to practice and test their understanding in authentic use and the potential to produce authentic texts of their own. This may be seen as the ramification in the section 'language in use', Figure 4, in which the students must return to the text to notice certain required structures.

4 Notice here the purposeful use of "considered'. This is because an authentic text may have different language structures, so that we are not bound to work only with studied structures in this section, since it tests reading comprehension. The purpose here is to gather information on what students can do when considering their reading skills, not limited to grammar and vocabulary use skills. Although the choice of such stimulus, presenting these structures adds to the contextualized use of language, precious to both Critical Literacy and the Communicative Approach. 
There is a significant opportunity to work with texts in ways that elicit Critical Literacy practices. For instance, the text in the reading section presents a situation that happened to a prominent figure of the music industry, the choices they made and contemplated consequences. It prompts the reader to an understanding of the use of a person's voice to help others, and, in doing so, to promote social change using their voice. We also catered to the use of different genres (music, news piece with embedded interview, for example), which is also a principle of both the Communicative Approach and Critical Literacy, as social literacy practices never stick to one or two (or even a few) possible genres.

In the reading section, as a stimuli text, we have chosen to use a text related to the fight between Rihanna (the award-winning singer) and her boyfriend Chris Brown $^{5}$, since we had already approached the theme of violence against women during the course. The text included a statement from the singer on her decision to speak about the incident to serve as an example to other women in the same situation. Figure 2 below represents the part of the original text that was included in the test:

Figure 2. Final Written Test, Reading Text

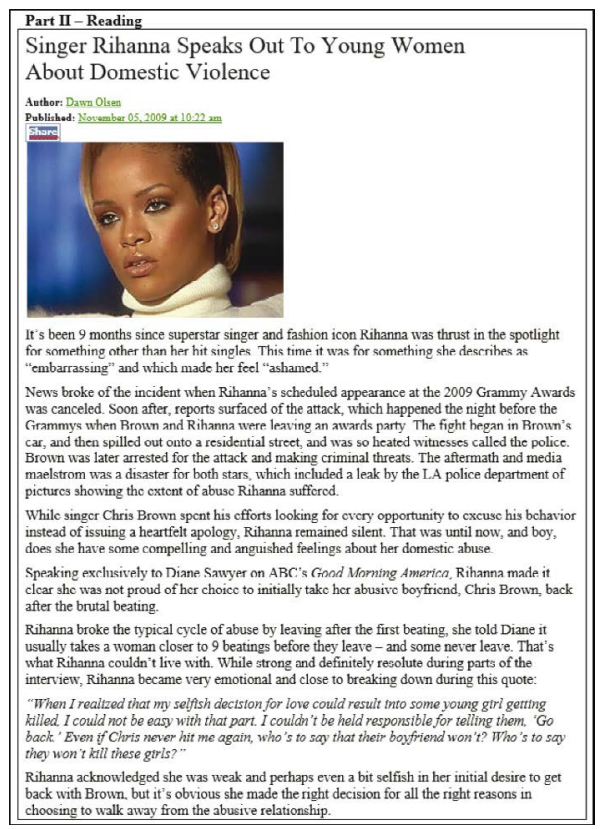

5 Available at http://technorati.com/entertainment/article/singer-rihanna-speaks-out-toyoung/ (Last accessed on July 2, 2011). 
The reading comprehension component of the test focused on the critical theme of keeping silent after suffering domestic violence. Figure 3 shows the two main questions on this issue:

FiguRe 3. Final Written Test, Reading Comprehension Questions

a) Why didn't Rihanna go to the 2009 Grammy Award?

b) How long did Rihanna remain silent after the incident?

These questions have a few things in common with the listening tasks, particularly the fact that they are open-ended questions. Besides, the task to which the questions belong is authentic and communicative and critical thinking is called for. To answer these questions, students were supposed to read the text and focus on the critical incident of domestic violence reported in it. Moreover, an important part of Rihanna's interview was highlighted in italics, namely the part in which she refers to her reasons for ending the abusive relationship. This is another teachable moment in which the test helps students further develop their critical awareness on the issue, and emphasizes textual multimodality in the genre "news" (Kress 2003; Kress \& Van Leeuwen 2006).

In addition, following the precepts of the Communicative Approach (Mattos \& Valério 2010; Valério \& Mattos 2018), grammar and vocabulary issues were always used in contextualized ways. The section on "language in use" used sentences and contents of the reading text to evaluate students' learning in relation to the grammatical points addressed in the course, rather than isolated and decontextualized phrases. Figure 4 represents the section on Language in Use:

FIGURE 4. Final Written Test, Language in Use

\begin{tabular}{|c|c|}
\hline \multicolumn{2}{|c|}{$\begin{array}{l}\text { Part III - Language in Use } \\
3 \text { - Go back to the text and underline all the verb phrases that contain a modal. Rewrite these vert } \\
\text { phrases below and state the meaning they convey: }\end{array}$} \\
\hline \multicolumn{2}{|c|}{$\begin{array}{l}\text { 4-Rewrite the sentences below using the modals provided on the right in a way that they } \\
\text { keep the same meaning of the original sentence: }\end{array}$} \\
\hline a) Rihanna surely felt embarrassed and ashamed of what happened. & MUST \\
\hline b) It would have been good if Chris Brown had apologized. & SHOULD \\
\hline c) It was wrong that Rihanna went back with Chris. & SHOULDN'T \\
\hline $\begin{array}{l}\text { d) Perhaps Rihanna has been weak and selfish in her desire to forgive } \\
\text { Brown. }\end{array}$ & MIGHT \\
\hline
\end{tabular}

Alicante Journal of English Studies, Issue 36, 2022, pages 29-53 
As it is possible to see, the two grammar tasks focus on Modals, which is the linguistic focus of the two final projects in the course. Although the tasks focus on grammar, the sentences used to test students' knowledge of modals are contextualized in the reading text from the previous section. Students have the chance to go back to the text and reread it, if they are unsure about the meaning of the modals (task 3 above). The sentences in task 4 are not isolated sentences either. They are all based on ideas represented in the text, although they were not literally taken from the text. In this way, students have a better chance of responding to the sentence transformation task correctly and/or learning with these tasks. The task also allows students to create sentences that may express their critical takes on the subject at hand, their own analysis of the facts. Once again, the levels of reliability and practicality suffer, but the task validity has good levels, since students can demonstrate their understanding on the uses of the modal verbs from the task and, by the same token, can express their voices.

\subsection{The Writing Section}

In terms of written production, during the course students had learnt about paragraph structure. This is the information we needed to gather in the end of the students learning process. As the genre is pre-set (the paragraph), we contextualized the writing task to the theme from the Reading section; the students will use their knowledge on violence and bullying, topics which were discussed during the course, to solve a problem they choose from the task proposal. They will be engaging in a thinking process that is focused on power struggles, social injustice and taking a step towards social change. Through this task, we were able to assess what students had learnt about paragraph structures, and the students will get feedback that will help them in understanding and revising their writing. Finally, we were also able to have feedback about the social impact of discussions held in class, which allowed for reflection on our praxis and planning for forthcoming courses.

The written task in the Final Test and the Oral Test also dealt with the themes already used and debated in the classroom. Figure 5 shows the examples of questions included in the writing section of the Final Test.

As discussed in Mattos (2014), after debating these themes together for a whole semester, students had enough vocabulary to talk about the topics, but they still had to prepare the written text, that is, the paragraph, at the time of the test. Therefore, students had to organize their ideas in an academic paragraph, using vocabulary and grammar topics learned during the course. We believe this was again a further opportunity for them to rethink the topics discussed during the course and display their own understanding of these critical issues, once again expressing their voices. 


\section{Figure 5. Final Written Test, Writing Part}

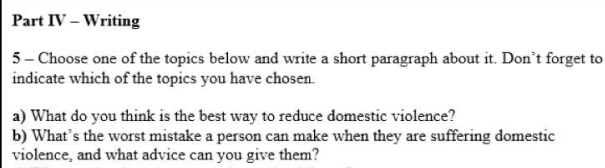

\subsection{The Oral Test}

Oral tests are well-known for being the nightmare of every foreign/second language learner (Mattos 2000). To diminish this thrilling sensation in our students, we created prompts based on the same topics discussed during the whole semester. In this way, they had already compiled a range of background knowledge, since the classroom debates, and the course activities in general, gave them the necessary tools in terms of vocabulary and grammar, working as a scaffold without, however, putting words in their mouths (Mattos 2000).

In addition, during the semester, the speaking practices were focused on students' needs in future academic practices, such as small group discussions, whole-class discussions and short speeches in vlogs. Therefore, the oral test needed to focus on one of those practices. Due to time and number of students enrolled in the course, the short group discussion was the best choice in our context. Therefore, groups of 4-5 students were tested together, simulating small group discussions, which they were already acquainted with.

The goal of the test was to gather information on students speaking skills in group discussions. The prompts (see Appendix) designed as input for the test involved situations proposing problem solving discussions in different contexts students might face in the present or in their future professional practices. They were invited to engage with their group members and talk about their opinion, coming up with answers to the prompts and developing a line of thought. They could also engage in practices that involve authorship and instructional goals, as presented in Table 1-first because the prompts allowed for the possibility of different opinions and beliefs to come up, and the perception of meaning as multiple, contested and culturally situated; thus, the instructional goals were used as a means to develop critical consciousness.

\section{Conclusion}

The course segment presented in this paper is based on Critical Literacy perspectives trying to put together the precepts of the Communicative Approach, 
as suggested by Valério and Mattos (2018). In doing so, we have discussed several principles for developing critical literacy tasks and activities for language tests, be them formative or summative. The main limitation we have found in trying to develop and apply Critical Literacy principles in testing and assessment in an English course at university level was the lack of background theories and example practices that we could use to depart from. Therefore, such principles, although still in their embryonic stage and lacking further reflections, may help develop future research and practices in language testing from a Critical Literacy perspective.

Two of the formal assessment instruments used in the course and discussed in this paper, i.e. a written and an oral test, were offered as means for comprehending how critical approaches can be part of the pedagogical practices in language classrooms as a whole - being explored in teaching, learning and assessment processes. Especially when considering that teaching and learning do not cease when an assessment takes place, which leads us to believe that assessments are teachable and learnable moments - just as assessments can be informal and can happen during teaching and learning.

As we have discussed, it is possible to use tests and assessment opportunities to further teachable moments, including critical issues pertaining to the realm of Critical Citizenship Education. Wielewick says that "one of the basic aspects of how schooling is structured, in general, is evaluation" and adds that "learning at school is disconnected from what is done in the 'real' world" $(2011,55)$. She suggests that critical literacy may be a way to contribute "to a better articulation of schooling with the real contexts of production, dissemination and reception, or consumption, of texts" $(2011,57)$. However, the author questions how we may be able to accomplish this, if we remain clinged to traditional, conventional molds of practices, including in evaluation. Thus, she asserts that "school may and must contribute to citizens' critical positioning" $(2011,57)$. In our view, the examples discussed in this paper may be a possibility for introducing Critical Literacy not only in teaching, but also in assessment practices.

Just as Education may be "not merely formative, but also transformative" (Wenger 1998, 263), in our view the same can be said about tests.

\section{Acknowledgements}

The authors would like to thank the anonymous reviewer for helpful feedback on the first version of this paper. 


\section{Works Cited}

Alderson, J. Charles and Jayanti Banerjee. 2001. "Language Testing and Assessment (Part I).” Language Teaching 32: 213-236. https://doi.org/10.1017/ S0261444800014464

-. 2002. "Language Testing and Assessment (Part II)." Language Teaching 35: 79-113.

Alderson, J. Charles and Arthur Hughes, eds. 1981. Issues in Language Testing (ELT Documents, v. 111). London: The British Council.

Bobkina, Jelena; and Svetlana Stefanova. 2016. "Literature and critical literacy pedagogy in the EFL classroom: Towards a model of teaching critical thinking skills." Studies in Second Language Learning and Teaching 6: 677-696. https://doi.org/10.14746/ssllt.2016.6.4.6

Bond, Guy L. and Eva B. Wagner. 1966. Teaching the Child to Read. 4th ed. New York: Macmillan.

BoraIE, Deena. 2018. “Types of Assessment.” In Liontas 2018, 5291-5297.

Brazil. 2006. Orientações curriculares para o ensino médio: linguagens, códigos e suas tecnologias - conhecimentos de línguas estrangeiras. Brasília: Ministério da Educação / Secretaria de Educação Básica. http://portal.mec.gov.br/seb/arquivos/pdf/book_ volume_01_internet.pdf. [Accessed online on Feb. 6, 2008]

Brown, H. Douglas. 2004. Language Assessment: Principles and Classroom Practices. New York: Person.

Castell, Suzanne De, Allan Luke and D. Maclennan. 1986. "On Defining Literacy." In Castell, Luke and Egan 1986, 3-14.

-., eds. 1986. Literacy, Society, and Schooling: A Reader. Cambridge: Cambridge UP.

Cervetti, Gina, Michael J. Pardales and James S. Damico. 2001. "A Tale of Differences: Comparing the Traditions, Perspectives and Educational Goals of Critical Reading and Critical Literacy." Reading Online 4: n. p. http://www.readingonline.org/ articles/art_index.asp?HREF $=/$ articles/cervetti/index.html [Accessed online on Mar. 30, 2007]

Crookes, Graham V. 2013. Critical ELT in Action: Foundations, Promises, Praxis. New York: Routledge. https://doi.org/10.4324/9780203844250

Davis, J. M. 2018. “Terminology: Assessment, Evaluation, and Testing.” In Liontas 2018, 5255-5261.

Dooley, K., Beryl Exley and David Poulus. 2016. "Research on Critical EFL Literacies: An Illustrative Analysis of Some College Level Programs in Taiwan." English Teaching and Learning 40: 39-64.

Duboc, Ana P. Martínez. 2013. "Teaching with an Attitude: Finding Ways to the Conundrum of a Postmodern Curriculum." Creative Education 4: 58-65. https://doi.org/10.4236/ce.2013.412A2009 
EsQuivel, Johanna. 2019. "Embodying Critical Literacy in a Dual Language Classroom: Critical Discourse Analysis in a Case Study." Critical Inquiry in Language Studies 17: 206-227. https://doi.org/10.1080/15427587.2019.1662306

FERraz, D. M. 2010. "EELT - Education through English Language Teaching in a Brazilian Technical School." Revista Crop 15: 102-119. http://200.144.182.130/ revistacrop/images/stories/edicao15/v15a07.pdf. [Accessed online on May 6, 2017]

-. 2015. Educação Crítica em Língua Inglesa: Neoliberalismo, Globalização e Novos Letramentos. Curitiba: CRV.

Freire, Paulo. 1975. Pedagogia do Oprimido. Rio de Janeiro, Brazil: Paz e terra.

-. 1982. Educação como Prática da Liberdade. Rio de Janeiro, Brazil: Paz e Terra.

-. 1984. A Importância do Ato de Ler. São Paulo, Brazil: Cortez.

FreIRE, Paulo and Donaldo Macedo. 1987. Literacy: Reading the Word and the World. New York: Continuum.

Fulcher, Glenn and Fred Davidson. 2007. Language Testing and Assessment: An Advanced Resource Book. New York: Routledge. https://doi.org/10.4324/9780203449066

Genesee, Fred and John A. Upshur. 1996. Classroom-based Evaluation in Second Language Education. New York: Cambridge UP.

Goertel, R. A. 2018. "Classroom comprehension assessment." In Liontas 2018, 2053-2058. https://doi.org/10.1002/9781118784235.eelt0492

GonçAlves, Glaucia R., Sandra. R. G. Almeida, Vera L. M. O. Paiva and A. S. Rodrigues Junior, eds. 2009. New Challenges in Language and Literature. Belo Horizonte: FALE/UFMG.

Grillo, M. C. and V. M. R. Lima. 2010. "Especificidades da Avaliação que Convém Conhecer." In: Grillo and Gessinger 2010.

Grillo, M. C. and R. M. Gessinger, eds. 2010. Por que Falar Ainda em Avaliação? Porto Alegre: ediPUCRS.

Hancock, C. 2006. "Language Teaching and Language Testing: A Way and Ways to Make Appropriate Connections." Acción Pedagógica 15: 6-13. http://www.saber.ula.ve/ bitstream/handle/123456789/17276/articulol.pdf?sequence $=2$ \&isAllowed =y. [Accessed online on Dez. 12, 2017]

Hawkins, Margaret R., ed. 2011. Social Justice Language Teacher Education. Bristol,

UK: Multilingual Matters https://doi.org/10.21832/9781847694249

Hughes, Arthur. 1989. Testing for Language Teachers. Cambridge: Cambridge UP. HuH, Seonmin. 2016. "Instructional Model of Critical Literacy in an EFL Context: Balancing Conventional and Critical Literacy." Critical Inquiry in Language Studies 13: https://doi.org/10.1080/15427587.2016.1154445 
JANKS, Hilary. 2013. "Critical Literacy in Teaching and Research.” Education Inquiry 4: 225-242. https://doi.org/10.3402/edui.v4i2.22071

Jordão, C. M., J. Z. Martinez and Mór W. Monte, eds. 2018. Letramentos em Prática na Formação Inicial de Professores de Inglês. Campinas: Pontes.

KRESS, Gunther. 2003. Literacy in the New Media Age. London: Routledge. https://doi.org/10.4324/9780203299234

KRESS, Gunther and Theo Van Leeuwen. 2006. Reading Images: The Grammar of Visual Design. 2. ed. London/New York: Routledge. https://doi.org/10.4324/9780203619728

LIONTAS, John I., ed. 2018. The TESOL Encyclopedia of English Language Teaching. Singapore: Willey. https://onlinelibrary.wiley.com/doi/ book/10.1002/9781118784235. [Accessed online on July 14, 2018] https://doi.org/10.1002/9781118784235

LuCKesı, C. C. 2008. Avaliação da Aprendizagem Escolar. São Paulo, Brazil: Cortez.

Mclaughlin, Maureen and Glenn L. Devoogd. 2004. Critical Literacy: Enhancing Students' Comprehension of Text. New York: Scholastic.

Matros, Andrea M. A. 2000. "A Vygotskian Approach to Evaluation in Foreign Language Learning Contexts." ELT Journal 54: 335-345. https://doi.org/10.1093/elt/54.4.335

-. 2014. "Educating Language Teachers for Social Justice Teaching." Interfaces Brasil/ Canadá 14: 125-151. https://periodicos.ufpel.edu.br/ojs2/index.php/interfaces/ article/view/6738/4644. [Accessed online on May 6, 2017]

-. 2018a. "Formação Crítica de Professores: Por uma Universidade Socialmente Responsável.” In Jordão, Martinez and Monte Mór 2018, 83-105.

-. 2018b. "English Teacher Critical Education in Brazil." In: Liontas, J. I., ed. The TESOL Encyclopedia of English Language Teaching. Singapore: Willey. https:// onlinelibrary.wiley.com/doi/abs/10.1002/9781118784235.eelt0929. [Accessed online on July 14, 2018]

Mattos, Andrea M. A., D. M. Ferraz and W. Monte Mór. 2015. Letramentos e Formação de Professores de LE. III CONEL-Congresso Nacional de Estudos Linguísticos, Universidade Federal do Espírito Santo (UFES). Oral Presentation.

Mattos, Andrea M. A. and K. M. Valério. 2010. "Letramento Crítico e Ensino Comunicativo: Lacunas e Interseções." Revista Brasileira de Linguística Aplicada 10: https://doi.org/10.1590/S1984-63982010000100008

Monte Mór, W. 2009. "Foreign Languages Teaching, Education and the New Literacies Studies: Expanding Views.” In Gonçalves, Almeida, Paiva and Rodrigues Junior, eds. New Challenges in Language and Literature. Belo Horizonte: FALE/UFMG. p. 177-189. 
Morgan, Wendy. 1997. Critical Literacy in the Classroom: The Art of the Possible. New York: Routledge.

Mulık, K. and M. S. Retorta, eds. 2014. Avaliação no Ensino-Aprendizagem de Línguas Estrangeiras: Diálogos, Pesquisas e Reflexões. Campinas: Pontes.

Norton, Bonny and Kelleen Toohey, eds. 2004. Critical Pedagogies and Language Learning. New York: Cambridge UP. https://doi.org/10.1017/ CBO9781139524834

O'Sullivan, Michael and Karen Pashby, eds. 2008. Citizenship Education in the Era of Globalization: Canadian perspectives. Rotterdam: Sense. https://doi.org/10.1163/9789087905910

PALmer, Adrian S. and Lyle F. Bachman. 1981. "Basic Concerns in Test Validation." In Alderson and Hughes 1981, 135-151.

Pascoal, Lílian A. V. 2018. "Avaliações escritas de Língua Inglesa em contextos de extensão e formação de professores: possíveis relações com letramento crítico." M.A. Thesis. Federal University of Minas Gerais, Brazil.

Pennycook, Alastair. 2001. Critical Applied Linguistics: A Critical Introduction. Mahwah, New Jersey: Lawrence Erlbaum. https://doi.org/10.4324/9781410600790

Quevedo-Camargo, G. 2014. "Efeito Retroativo da Avaliação na Aprendizagem de Línguas Estrangeiras: Que Fenômeno É Esse?” In Mulik and Retorta 2014, 7188.

RichARDS, Jack C. and Richard Schmid. 2010. Language Teaching and Applied Linguistics. London: Pearson.

Scaramucci, M. R. V. 2011. "Validade e Consequências Sociais das Avaliações em Contextos de Ensino de Línguas." Linguarum Arena 2: 103-120.

Shoнamy, Elana. 2004. "Assessment in Multicultural Societies: Applying Democratic Principles and Practices to Language Testing." In Norton and Toohey, K. 2004, 72-92. https://doi.org/10.1017/CBO9781139524834.005

SOARES, M. 1998. Letramento: Um Tema em Três Gêneros. 2. ed. Belo Horizonte: Autêntica.

UR, Penny. 1996. A Course in Language Teaching: Practice and Theory. New York: Cambridge UP.

VAlÉrio, K. M. and A. M. A. Mattos. 2018. "Critical Literacy and the Communicative Approach: Gaps and Intersections.” Revista Brasileira de Linguística Aplicada 18: 313-338. https://doi.org/10.1590/1984-6398201812252

Vetter, Diane. 2008. "Towards a Critical Stance: Citizenship Education in the Classroom." In O'sullivan and Pashby 2008, 105-111. https://doi. org/10.1163/9789087905910_009

Wenger, Étienne. 1998. Communities of Practice: Learning, Meaning and Identity. Cambridge: Cambridge UP. https://doi.org/10.1017/CBO9780511803932 
Wielewicki, V. 2011. "Letramento Literário e Avaliação: Empalhando a Borboleta?" Revista X 1: 48-58. https://revistas.ufpr.br/revistax/ article/view/24551/16916. [Accessed online on Dec. 2, 2011] https://doi.org/10.5380/rvx.vli1.24551

\section{Appendix}

\section{Prompts for the Oral Test}

1. You are a group of university students. One of your teachers has asked you to write a paper discussing the problems that having stereotypes can bring to the modern society. In your group, discuss what you would like to include in the paper.

2. You are teachers in a public school. Your coordinator has told you that there is going to be a meeting with the school principal to discuss the problems that stereotypes may cause in the school and the actions and attitudes that teachers should have. In your group, discuss what you would like to tell the principal.

3. You are a group of teachers that work with very young children. You believe it is your role to prepare these children for future insertion in our society, and you are worried about how to prepare boys and girls equally for future jobs that they may want to take. In your group, discuss the differences between boys and girls and the reasons that might make them so different.

4. You are teachers in a public school. Your school has just been selected for o governmental program that will give one computer for each of the students in the school so that they will be able to have access to the Internet during classes. You want to get prepared for these changes and want to think of ways of using the Internet in your classes. In your group, discuss some advantages and disadvantages of the Internet.

5. You are a group of teachers in a public school. Your school principal has asked you to prepare a report discussing some ways to reduce bullying in the school to be presented at a whole-school meeting. In your group, discuss what you would like to include in the report.

6. You are a group of teachers who have had a few problems with bullying in your classes You are planning together a meeting with all the parents of your students. In your group, discuss the mistakes that parents make when their child is being bullied, so that you can better advise the parents during the meeting.

7. You are a group of teachers who have had a few problems with bullying in your classes You are planning together a meeting with all the parents of your students. During the meeting, you want to give advice to the parents on how to help their kids face bullying. In your group, discuss what you would say to the parents.

8. You are a group of school principals from different areas in the city, who have been selected to talk to the Secretary of Education about a problem that is recurrent in your schools: bullying. You want to suggest several ways for schools to prevent bullying. In your group, discuss what you would say to the Secretary of Education.

Alicante Journal of English Studies, Issue 36, 2022, pages 29-53 